\title{
Data report: interpretation of cored intervals with greater than one hundred percent core recovery: IODP Expedition 313 used as an example methodology'
}

\author{
J. Inwood ${ }^{2}$
}

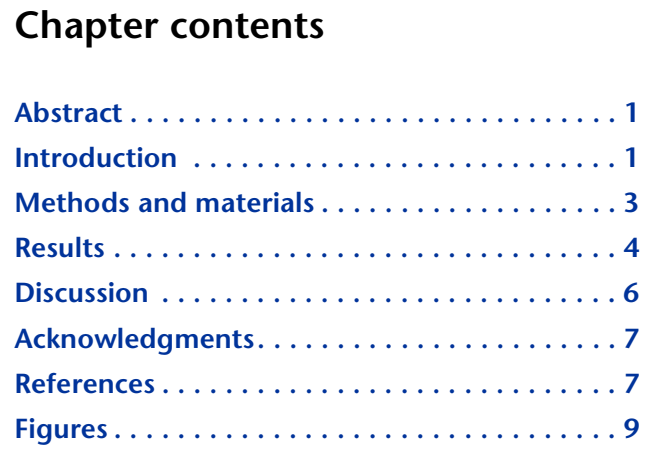

'Inwood, J., 2018. Data report: interpretation of cored intervals with greater than one hundred percent core recovery: IODP Expedition 313 used as an example methodology. In Mountain, G., Proust, J.-N., McInroy, D., Cotterill, C., and the Expedition 313 Scientists, Proceedings of the Integrated Ocean Drilling Program, 313: Tokyo (Integrated Ocean Drilling Program Management International, Inc.).

doi:10.2204/iodp.proc.313.202.2018

${ }^{2}$ School of Geography, Geology and the Environment, University of Leicester, University Road, Leicester LE1 7RH, United Kingdom. ji18@le.ac.uk

\begin{abstract}
Conventionally, depths of core recovered during a drilling and coring expedition are determined by placing the top of the recovered core at the top of the core barrel run that recovered it. During many ocean drilling expeditions, certain intervals of core recovered from a drill run are recorded as $100 \%$ or greater, resulting in an overlap in core depths between adjacent runs. There are various reasons for these overlaps; significantly, the presence of clay that expands on recovery, as well as other possibilities including gas expansion, slipped cores recovered by subsequent runs, and disturbances during drilling leading to retrieval of surplus loose material. These intervals of overlap require cautious treatment to avoid potential confusion in analysis if different cores are sampled at apparently equivalent depths. Scientists need to be precise in the explanation of their method of dealing with any such overlaps.

During Integrated Ocean Drilling Program Expedition 313, a mixture of siliciclastic sediments were recovered from three sites on the New Jersey shallow shelf. This report identifies intervals of core overlap from the conventional depth determination and analyzes their origin by combining core lithologic observations with notes taken during drilling operations and recorded drilling parameters. Drilling parameters represent an underutilized resource in the interpretation of core recovered during drilling, especially for measurements in which assumptions are made on the quality of the core. Downhole logs provide independent depth control and, through analysis in tandem with equivalent core petrophysical measurements, an evaluation can be made of how to optimally deal with overlapping core intervals. The advantages of the methodology presented go beyond the Expedition 313 examples illustrated here and could be applied to other expeditions.
\end{abstract}

\section{Introduction}

Detailed correlation and accurate depths are a cornerstone of many Integrated Ocean Drilling Program (IODP) expeditions, and Expedition 313 New Jersey Shallow Shelf was no exception. Siliciclastic sediments were drilled and recovered at three sites on the New Jersey shallow shelf, with overall expedition aims that included the evaluation of sequence stratigraphic facies models. Detailed correlation is important for sequence stratigraphic studies 
both at the scale of the margin (e.g., Mountain et al., 2010; Miller et al., 2013) but also for smaller scale studies, especially where key intervals fall within intervals of overlap (e.g., Nilsson et al., 2013; Inwood et al., submitted).

Overlaps in core depth can originate from different processes (Ruddiman et al., 1987), including gas expansion (e.g., Flood, Piper, Klaus, et al., 1995), sediment rebound (e.g., Moran, 1997), clay swelling (e.g., Mountain et al., 2010; Saffer et al., 2011; Daigle and Piña, 2016), or drilling disturbances such as a slipped core being recovered by a subsequent run or reaming (e.g., see the "Methods" chapter [Expedition 313 Scientists, 2010a]). During paleoceanographic expeditions, it is common to produce a composite depth splice from more than one borehole, the final result of which often indicates 10\%-20\% expansion (Hagelberg et al., 1992, 1995; Lisiecki and Herbert, 2007), thus indicating the importance of appropriately dealing with core expansion for each scientific study. The purpose of this data report is to produce an overview of the three Expedition 313 sites, identify all intervals of core overlap, and evaluate their origin, along with discussion of the optimum way to deal with depth in these intervals.

In intervals of clay lithology, it is common to recover more than $100 \%$ core, which results in an apparent overlap in depth and is generally due to the hydration of clay minerals causing expansion (Anderson et al., 2010). Swelling clay is often noted during drilling or borehole logging operations, including during Expedition 313 (see the "Methods" chapter [Expedition 313 Scientists, 2010a]). Clay can refer to the size of the particles in a rock or to a clay mineralogy. Clay minerals belong to the group of hydrous aluminosilicates and have maximum particle dimensions of $<0.005$ mm (e.g., Meunier, 2006); kaolinite, smectite, and illite are the three main clay groups (Grim, 1953). For Expedition 313, clay was defined by particle size, but most of the recovered New Jersey sediments contain some component of clay minerals, including kaolinite, micas, illite, mixed-layer clays, and smectite (Mountain et al., 2010). For example, clay minerals make up as much as $59.2 \%$ of the clay recovered from Hole M0027A, which was measured by X-ray diffraction (XRD) (Mountain et al., 2010). The degree of clay expansion (swelling clay) varies depending on the clay type. For example, some clay (e.g., bentonite) can swell to $>20$ times its original size, although the quantification of the degree of swelling based on clay composition is not straightforward (Anderson et al., 2010).

Overlaps in nonclay lithologies (e.g., in sandy intervals) can be due to drilling-related disturbances.
Many of these disturbances are apparent from observation of the core. For example, typical features are described and illustrated for International Ocean Discovery Program Expedition 354 (France-Lanord, Spiess, Klaus, Schwenk, and the Expedition 354 Scientists, 2016), including fall-in (material falls into the borehole), core biscuits (broken-up pieces of core), flow-in (material from outside the borehole flows into the drilled sediments), voids, fractures, and soupy (liquid) cores. Such drilling disturbances in the core were described and recorded graphically on the visual core description (VCD) images by the Expedition 313 sedimentologists (see "Core descriptions"). However, visual observation of these features does not necessarily identify all disturbances, and reports of disturbance do not always correlate with the measured degree of core extension (Lisiecki and Hebert, 2007). Drilling data, including notes taken during drilling operations as well as semiquantitative drilling parameters (physical forces and pressures during drilling), can be essential in identification of drilling disturbance. However, these data are rarely incorporated into later scientific studies, even where incorporation could be valuable. This is likely due to a combination of a lack of availability of requisite data/information (e.g., drilling parameters) and to a lack of knowledge. Additionally, drilling parameters are collected in time rather than in depth, which adds complexity to the analysis and integration with the core and downhole logging data that are collected in depth. Past research has shown the value of incorporating drilling parameters for the interpretation of characteristics such as cavities or formation strength (e.g., Sugawara et al., 2003; Inwood et al., 2008; Kinoshita, Tobin, Moe, and the Expedition 314 Scientists, 2008), especially where technology exists to convert these measurements directly into depth by systems that record the time and depth of the drill string below the rig floor (e.g., Flemings, Behrmann, John, and the Expedition 308 Scientists, 2006; Inwood et al., 2008). During Expedition 313, drilling parameters were recorded in time, but they can still be of use. A number of interrelated measurements were taken, including number of revolutions of the drill bit per minute (head rpm), torque pressure, water pressure, and weight on bit (see the "Methods" chapter [Expedition 313 Scientists, 2010a]). Water pressure (pullback pressure or hydraulic pressure) is the inverse of bit weight and is necessary to prevent the drill bit from resting on the formation without any control. Torque relates to oil pressure on the drill motor and depends on the gear used. Higher head rpm can indicate a faster drilling rate. These parameters provide semiquantitative information in that, providing external parameters are 
constant, a change in an individual parameter indicates a change in formation properties (e.g., lithology).

Once overlaps and their origins have been identified, it is common to decide on a method to avoid the confusion of two data points at seemingly equivalent depths (refer to IODP Depth Scales Terminology at http://www.iodp.org/top-resources/programdocuments/policies-and-guidelines). One simple method is to ignore the data from one of the cores within the overlap interval (either the upper or lower core). An alternative for numerical data is to average measured data in these intervals. However, neither of these scenarios are ideal for more-detailed studies or for intervals around key surfaces where a wrong assumption may wrongly correlate a misleading feature. Scaling in these intervals is one way of treating these intervals, for which there are several variations, such as scaling per core or by an overall factor. Downhole logging data can be valuable because they represent independent depth control, and where analogous measurements exist on both the recovered core and downhole logs, an accurate solution can be proposed with confidence (e.g., Gilbert and Burke, 2008; Inwood et al., 2008; Fontana et al., 2010; Clary et al., 2017). For Expedition 313, both natural gamma radiation (NGR) and magnetic susceptibility measurements could be used in this way to help interpret core overlaps, as both measurements were acquired in situ during downhole logging and on the recovered core material.

An overview (Fig. F1) of all three Expedition 313 sites indicates the location of and interpretations for core overlaps (provided in larger scale in OverlapsSummary_detail.ai in OVERLAP in "Supplementary material"). Examples of the usefulness of the drilling data are illustrated for two intervals in Hole M0027A (Figs. F2, F3). The latter part of this report focuses on two key intervals of clay expansion in Holes M0027A and M0028A (Figs. F4, F5) and illustrates the value of downhole magnetic susceptibility logging data to correct depths in overlaps in Hole M0027A (Fig. F6).

\section{Methods and materials}

Overlaps were identified from the curated expedition depths by rounding all depths to the nearest $1 \mathrm{~cm}$ and then identifying repeated depths and categorizing these into

- Overlap A, referring to overlap within the overlying core above and

- Overlap B, referring to overlap in the underlying core.
Material is collected at the very base of each run by metal blades referred to as "core catchers." In general, this material is minor (in the region of centimeters), is not logged for core physical properties, and is often not competent material. However, because this core catcher material provides part of the recovered core, two versions of the overlaps should be considered, the first version including these core catcher pieces and the second version excluding them. Physical property measurements of the core provide an additional machine-precise core length measurement with occasional minor discrepancies between these measurements and the curated core measurements. Because core catcher material is seldom long enough for measurement of core physical property data or for digital linescan image acquisition, scaled depths excluding core catchers are used for the remainder of this report (Fig. F1, column 5b). This exclusion results in a continuous digital image and ensures correspondence to the overlying core physical property data.

Lithology, based on observations made of the split core surfaces, was recorded during the expedition and described in the Lithology sections of the "Site M0027," "Site M0028," and "Site M0029" chapters (Expedition 313 Scientists, 2010b, 2010c, 2010d) and graphically in the VCDs. These records are supported by systematic high-resolution digital linescan images of the split core face of the archive half ( $\sim 62 \mathrm{~mm}$ diameter) of all core sections.

The Expedition 313 operational team and drillers recorded relevant observations during drilling, which is standard practice during expeditions. For example, the observation that the rate of penetration has changed may indicate a different lithology or the observation that a run recovered an empty core barrel potentially suggests the core has slipped and may be recovered by the subsequent run. For each interval of identified overlap, the notes taken during drilling operations were accessed for that core barrel to identify or rule out drilling-related disturbance causing the overlap. Consideration should also be given for excluding material that may be drilling in-fill or duplicated material. For this report, where intervals of overlap are found within clay lithologies, no recovered core is discounted for this reason. Elsewhere in the boreholes, visual evaluation of the degree of drilling disturbance (see the "Methods" chapter [Expedition 313 Scientists, 2010a]) is reinforced by the drilling notes, and the appropriateness of excluding material affected by drilling disturbance is most accurate by considering each individual core (Fig. F1).

Drilling parameter data were recorded in time and captured nearly continuously during drilling. The 
driller started and stopped the recording interval to coincide with drilling times. During Expedition 313 drilling parameter data were recorded in drilling data file format (DDF) in GMT - 8 (Pacific time) and converted by scientists (J. Inwood, G. Tulloch, and C. Delahunty) to expedition time (UTC - $5 \mathrm{~h}$; Eastern standard time) for Hole M0027A. Files for Hole M0027A were renamed in YYMMDD format. Each DDF file represents $\sim 2 \mathrm{~h}$ of operations, with the file size corresponding to seconds of recording time. Shorter files usually correspond to a pause in recording to enable file backup. Gaps exist where a driller accidentally turned the switch off (rare and typically short in duration); larger gaps in recording correspond to the switch being turned off while repairs or operational difficulties were resolved. The end time was recorded from file properties and metadata for all files imported into a single Microsoft Excel spreadsheet. The DDF files were input into the Racepak DataLink II program (https://store.racepak.com), which was designed for racing car systems and modified for drilling data by C. Delahunty. This program can output an ASCII file (WRI file extension) for a selected time interval ( $5 \mathrm{~s}$ was selected for Hole M0027A). A graph of selected properties (head rpm, torque force, and water flow) was produced (see M27DrillerInfoLog118to226.jpg in OVERLAP in "Supplementary material" for Runs 118-226). The drilling files were saved as individual files and combined into a single spreadsheet (see M27DrillFiles.xls in OVERLAP in "Supplementary material"), enabling careful correlation of the drilling time with the time that core was recovered on deck and sedimentological observations and the addition of each run number to the graph. Note that these correlations are estimates and may require minor adjustments in intervals for high-resolution studies.

Downhole logging data can be extremely useful as a tool for correlation between in situ data acquired in the borehole during logging and measurements and observations on core, especially where equivalent measurements (commonly NGR) are taken downhole and on the recovered core. During Expedition 313 , spectral gamma ray logs were acquired for the complete formation and NGR measurements were taken every $9 \mathrm{~cm}$ on the recovered core (Fig. F1; also see the "Methods" chapter [Expedition 313 Scientists, 2010a]). Magnetic susceptibility measurements, where acquired during downhole logging operations, represent an effective method of correlating in situ measurements and core measurements taken every $1 \mathrm{~cm}$ (see the "Methods" chapter [Expedition 313 Scientists, 2010a]).

Coring and wireline logging depths are based on the length of the drill pipe and length of the wireline be- low the seafloor, respectively. Both are referred to as meters below seafloor (mbsf) in the remainder of this report, which is sufficient to point the reader to the appropriate point on the figures. However, depths on figures are specified precisely following IODP Depth Scales Terminology (http://www.iodp.org/ top-resources/program-documents/policies-andguidelines) to enable depths across measurements to be compared.

\section{Results}

The identified overlaps in Holes M0027A, M0028A, and M0029A, including lithology and the degree of overlap for each core section, are illustrated in Figure F1. It is clear from this representation that overlapping intervals were identified across several lithologies, but almost all clay intervals display some overlap (e.g., around 200 mbsf) in Hole M0027A and 230 mbsf in M0028A. Relatively small overlaps occur at the base of each core run and are interpreted to be due to clay mineral expansion. This interpretation is supported by the drilling notes and drilling parameters, indicating that drilling was progressing well (Fig. F1, column 7). The expansion amount is generally $<10 \%$ (e.g., $7.52 \%$ in Hole M0027A and $11.23 \%$ in Hole M0028A; upper clays). Some larger overlaps also occur, generally in nonclay lithologies, and are interpreted to be due to slipped core, an interpretation generally confirmed by the drilling notes (e.g., at 517 mbsf in Hole M0027A, 298 mbsf in Hole M0028A, and 439 mbsf in Hole M0029A) (Fig. F1, column 7). These overlapping cores are characterized by gaps in recovery adjacent to the slipped core. In other intervals of overlap, drilling notes mention difficulties in drilling operations, such as needing to ream or reenter the hole (e.g., at 265 mbsf in Hole M0028A). Here the underlying core could be considered to be likely affected by drilling disturbance. A large interval of overlap also occurs in Hole M0028A between 322 and 334 mbsf and was caused by reentry of the drill pipe that created a slightly deviated borehole, as discussed in the "Site M0028" chapter (Mountain et al., 2010c), and has been shown as a separate narrow column to the left of the standard overlap columns (Fig. F1, Column 5*).

Each core run during drilling is marked by an increase in head rpm, water flow, and torque force. Where drilling went smoothly, there tends to be a fairly regular gap between core runs, and without anything external altering, any observed difference in drilling parameter values can be attributed to a change in the material being drilled (e.g., a lithologic change). This scenario can be observed on Figure F2 where sand changes to silt downhole at $414 \mathrm{mbsf}$ in 
Hole M0027A, which is recognized by a decrease in drilling parameters as the lithology changes from sand to silt, with fairly regular runs both above and below this depth. Overlaps in the silt, continuing deeper (Fig. F1), are therefore interpreted to be due to clay minerals within the silt, resulting in expansion. This is consistent with XRD measurements that indicate the presence of clay minerals in this interval (see the "Site M0027" chapter [Expedition 313 Scientists, 2010b]).

Where larger overlaps are identified, they are often due to slipped cores or difficulty during drilling operations. At 548 mbsf in Hole M0027A (Fig. F3), a gap in recovery occurs above Core 195R; therefore, moving this core upward is the appropriate depth shift. This core run can be identified in the drilling record by a brief spike in torque force and a note that a short $(10 \mathrm{~cm})$ run collected material from the previous run (Fig. F3). Similarly, the overlap at $517 \mathrm{mbsf}$ in Hole M0027A (Fig. F3) also correlates with the observation in the drilling notes that Core $183 \mathrm{R}$ is a slipped core. At $524 \mathrm{mbsf}$, an interval of identified overlap corresponds to a gap in time $(3 \mathrm{~h})$ in the drilling parameter record where the recording switch was turned off, which is common at any point where drilling and coring pauses in order to solve a technical issue. The initial run after the pause is likely to have also collected surplus material that had fallen into the hole; therefore, it is appropriate to treat the core from the upper overlapping core as the better quality core.

Cores in their conventional depth position and two different methods for dealing with the overlapping sections are illustrated in Figures F4 and F5, showing the upper intervals of clay in Holes M0027A and M0028A, respectively. Digital linescan images are shown in their conventional position (both as a single image and separated) and as an expanded image column. In the expanded image column, core below an overlap has been moved down by a linear shift corresponding to the amount of the overlap. Hence, the shift progressively increases as more overlaps are accounted for. The conventional image column omits the upper part of each underlying image if an overlap is present; therefore, any measurements taken in the overlap intervals should be treated with caution. The overall expansion amounts are, respectively, $7.52 \%$ and $11.23 \%$. These amounts are lower than for some clay-rich lithologies, and yet the expanded image column illustrates that the progressive increase in shift required to account for the expansion soon results in considerable displacement of cores relative to their conventional position. Figures F4 and F5 illustrate that without additional informa- tion, it is difficult to establish how to correct the overlap interval and where to use conventional expanded depths or scaled depths.

Expedition 313 downhole logs can provide the data to decide how to adjust the core depths appropriately by providing an independent depth control. Spectral gamma ray logs acquired throughout the Expedition 313 boreholes mostly display a good correspondence to NGR measurements taken on cores (Fig. F1, column 8). In intervals of lower recovery, where core is likely to be less accurately positioned, especially if overlaps also complicate the recovered sequence (e.g., 70-100 mbsf in Hole M0027A or 265295 mbsf in Hole M0028A; Fig. F1), the correspondence is harder to identify between downhole logs and core, with the logs having better depth control. However, in some intervals, NGR measurements do not display a sufficient degree of variation for unambiguous depth control (e.g., 225-255 mbsf in Hole M0028A). Here, other downhole logs can be more helpful, such as magnetic susceptibility.

To assess the optimum correction for core depths, Figure $\mathrm{F} 6$ shows in detail an example of a $6 \mathrm{~m}$ interval in Hole M0027A, with magnetic susceptibility measured on the recovered core (dark blue) as well as downhole logging magnetic susceptibility (light blue) overlain on (1) conventional, (2) scaled, and (3) expanded core sequences. The core magnetic susceptibility is shown on a logarithmic scale when overlain on the conventional and scaled images. A linear scale is selected for the core magnetic susceptibility overlain on the expanded image column to illustrate how clearly this picks up the color banding in the clay in Core $69 \mathrm{X}$ and at the top of Core $70 \mathrm{X}$. The core magnetic susceptibility measurements indicate three main changes across this $6 \mathrm{~m}$ interval, designated by letters A through C (Fig. F6, Columns 57 ). From the base of the figure, Cores $73 \mathrm{X}$ through 70X display low, near-constant magnetic susceptibility until two successive increases uphole in Core 70X, first a change (at A) to a slightly higher, more variable magnetic susceptibility followed by a further increase uphole (at B) within the clay. Between Cores $70 \mathrm{X}$ and 69X, magnetic susceptibility slightly increases (at $\mathrm{C}$ ), and larger variations correspond to the visible color banding. VCDs do not identify major changes in the sediment at A or B, with silty layers disappearing uphole at C (see the "Site M0027" chapter [Expedition 313 Scientists, 2010b]). The downhole magnetic susceptibility log displays two significant increases uphole (Fig. F6, Column 8) that are likely to correspond to the changes at $\mathrm{A}$ and $\mathrm{C}$ in the core logs; the change at B likely coincides with more minor changes in the downhole log. To discuss 
the complexity of correlation within the overlap interval illustrated in Figure F6, conventional, scaled, and expanded depths are compared:

- Conventional depth (left): the depth of change A in the conventional column corresponds well with the lowermost significant change in the downhole log (Fig. F6, track 8). The change in core magnetic susceptibility at B does not clearly correspond to either a visible change in the image or in the downhole log. Note that the change at $\mathrm{C}$ could be placed at either the top or base of the overlap interval, depending on whether data from the upper or lower core are used or an average is used (for numeric data). In the overlap, the overlying cores overprint the underlying cores (e.g., Core $69 \mathrm{X}$ overprints Core 70X). For numeric data (e.g., core magnetic susceptibility), a further option is to use an averaged value, and therefore caution is required to ensure contrasting data types are treated equivalently.

- Scaled depth (center): the core magnetic susceptibility change at A correlates with a minor change in the downhole magnetic susceptibility log (Fig. F6, track 8). For changes B and C, the scaled image (center) shows a good correlation to the downhole log, with change $\mathrm{B}$ coinciding with a minor change in the downhole log and change $\mathrm{C}$ reflecting the significant increase uphole in both core and downhole magnetic susceptibility.

- Expanded depth (right): all three significant changes (A through $C$ ) in the core magnetic susceptibility logs occur below the depth of the equivalent changes in the downhole magnetic susceptibility log. Hence, this depth scale is inappropriate for any scientific studies requiring knowledge of the true depth because the successive summation of overlaps quickly leads to a large depth offset.

The scaled depth avoids any ambiguity in which data are being used within an overlap and allows a continuous record of the succession. Although either conventional or scaled depths could represent a better correlation to the downhole logs for the change at $\mathrm{A}$, for the changes at $\mathrm{B}$ and $\mathrm{C}$ the scaled depth displays a closer correspondence. It should be noted that although downhole logs represent independent depth control, they are not without depth issues (e.g., wire expansion or sticking), and the true depth may be a combination of core and logging depths.

\section{Discussion}

For Expedition 313, the ability to correctly interpret the origin of the intervals of overlap and adjust their depths in a way that is consistent with the subsequent purpose of study is important for both research that concentrates on correlating core and seismic observations and research that studies specific intervals in more detail. In general, to avoid any loss of data resolution within an overlap, the most appropriate method is to scale core images and core measurements, thus removing the overlap, and to rely on correlation with the independent depth control provided by downhole logs to allow depth adjustments as deemed appropriate (e.g., as demonstrated by using the magnetic susceptibility logs in Hole M0027A; Fig. F6). What is clear is that if expansion is not considered, it would potentially lead to erroneous correlation between downhole logs and core sequences, with, for example, certain Expedition 313 sequence boundaries located within these intervals of overlap (see OverlapsSummary_detail.ai in OVERLAP in "Supplementary material"). Key examples discussed here include intervals in which the drilling record describes coring progressing well, where overlaps are inferred to be due to lithology (expanding clay in both Holes M0027A and M0028A; Figs. F4, F5). Elsewhere, notes about slipped cores or drilling operational issues enable a decision to be made on whether a core should be depth shifted upward (e.g., 517 mbsf in Hole M0027A; Fig. F3) or whether the overlying or underlying overlapping core is likely to more accurately reflect the true formation at that depth (e.g., 524 mbsf in Hole M0027A; Fig. F3).

A number of methods are used to deal with sequences of expanded core in IODP (see IODP Depth Scales Terminology at http://www.iodp.org/top-resources/program-documents/policies-and-guidelines). Each core that has $>100 \%$ recovery can be accordingly scaled back to $100 \%$, such as the clay intervals of Expedition 313 (e.g., Figs. F4, F5). Alternatively, a mean value (or maximum, to ensure no overlaps remain) can be calculated for expansion in a selected interval and each core can be scaled back by the same percentage. To remove all overlaps throughout the succession, scaling can be applied throughout. However, the ability to distinguish the nature of overlaps, as described in this report, enables more informed decisions to be made for each interval of overlap (e.g., Figs. F2, F3), with the appropriate procedure also guided by the requirements of the subsequent scientific analyses.

In summary, this data report demonstrates the advantages of combining observations made on the core with core petrophysical, downhole logging, and drilling parameters and drillers' notes to establish both the cause of overlaps and the optimum way to deal with them. This approach can be applied to most expeditions, including those, such as Expedi- 
tion 313, for which drilling data do not have an automatic conversion from time to depth.

\section{Acknowledgments}

Data were provided by the Integrated Ocean Drilling Program (IODP). Special thanks to Graham Tulloch of the British Geological Survey and Chris Delahunty of Drilling, Observation and Sampling of the Earth's Continental Crust for useful discussions and for the considerable time spent offshore unraveling a large number of individual drilling files to enable output correction to expedition time and therefore allowing me to begin the process of assigning run numbers to the data. Special thanks also to Ali Skinner for additional discussion on drilling parameters. Thanks to the Expedition 313 Science Party and associated researchers and staff for questions on overlapping intervals during the Onshore Science Party, which prompted revisiting the drilling notes and the subsequent production of an earlier version of OverlapsSummary_detail.ai in OVERLAP in "Supplementary material." Thanks to Sally Morgan for taking the time to read and comment on this manuscript. Thanks to the external reviewer for comments that enabled the manuscript to be improved.

\section{References}

Anderson, R.L., Ratcliffe, I., Greenwell, H.C., Williams, P.A., Cliffe, S., and Coveney, P.V., 2010. Clay swelling - a challenge in the oilfield. Earth-Science Reviews, 98(34):201-216. https://doi.org/10.1016/j.earscirev.2009.11.003

Clary, W.A., Worthington, L.L., Slagle, A.L., and Daigle, H., 2017. Data report: core-log-seismic integration and time-depth relationships at IODP Expedition 341 Southern Alaska Margin Sites U1420 and U1421, Bering Trough, Gulf of Alaska. In Jaeger, J.M., Gulick, S.P.S., LeVay, L.J., and the Expedition 341 Scientists, Proceedings of the Integrated Ocean Drilling Program, 341: College Station, TX (Integrated Ocean Drilling Program). https://doi.org/10.2204/iodp.proc.341.204.2017

Daigle, H., and Piña, O.L., 2016. Data report: permeability, consolidation properties, and grain size of sediments from Sites U1420 and U1421, offshore southern Alaska. In Jaeger, J.M., Gulick, S.P.S., LeVay, L.J., and the Expedition 341 Scientists, Proceedings of the Integrated Ocean Drilling Program, 341: College Station, TX (Integrated Ocean Drilling Program). https://doi.org/10.2204/ iodp.proc.341.201.2016

Expedition 313 Scientists, 2010a. Methods. In Mountain, G., Proust, J.-N., McInroy, D., Cotterill, C., and the Expedition 313 Scientists, Proceedings of the Integrated Ocean Drilling Program, 313: Tokyo (Integrated Ocean Drilling Program Management International, Inc.). https://doi.org/10.2204/iodp.proc.313.102.2010
Expedition 313 Scientists, 2010b. Site M0027. In Mountain, G., Proust, J.-N., McInroy, D., Cotterill, C., and the Expedition 313 Scientists, Proceedings of the Integrated Ocean Drilling Program, 313: Tokyo (Integrated Ocean Drilling Program Management International, Inc.). https://doi.org/10.2204/iodp.proc.313.103.2010

Expedition 313 Scientists, 2010c. Site M0028. In Mountain, G., Proust, J.-N., McInroy, D., Cotterill, C., and the Expedition 313 Scientists, Proceedings of the Integrated Ocean Drilling Program, 313: Tokyo (Integrated Ocean Drilling Program Management International, Inc.). https://doi.org/10.2204/iodp.proc.313.104.2010

Expedition 313 Scientists, 2010d. Site M0029. In Mountain, G., Proust, J.-N., McInroy, D., Cotterill, C., and the Expedition 313 Scientists, Proceedings of the Integrated Ocean Drilling Program, 313: Tokyo (Integrated Ocean Drilling Program Management International, Inc.). https://doi.org/10.2204/iodp.proc.313.105.2010

Flemings, P.B., Behrmann, J.H., John, C.M., and the Expedition 308 Scientists, 2006. Proceedings of the Integrated Ocean Drilling Program, 308: College Station, TX (Integrated Ocean Drilling Program Management International, Inc.). https://doi.org/10.2204/ iodp.proc.308.2006

Flood, R.D., Piper, D.J.W., Klaus, A., et al., 1995. Proceedings of the Ocean Drilling Program, Initial Reports, 155: College Station, TX (Ocean Drilling Program). https://doi.org/ 10.2973/odp.proc.ir.155.1995

Fontana, E., Iturrino, G.J., and Tartarotti, P., 2010. Depthshifting and orientation of core data using a core-log integration approach: a case study from ODP-IODP Hole 1256D. Tectonophysics, 494(1-2):85-100. https:// doi.org/10.1016/j.tecto.2010.09.006

France-Lanord, C., Spiess, V., Klaus, A., Schwenk, T., and the Expedition 354 Scientists, 2016. Bengal Fan. Proceedings of the International Ocean Discovery Program, 354: College Station, TX (International Ocean Discovery Program). https://doi.org/10.14379/ iodp.proc.354.2016

Gilbert, L.A., and Burke, A., 2008. Depth-shifting cores incompletely recovered from the upper oceanic crust, IODP Hole 1256D. Geochemistry, Geophysics, Geosystems, 9(8). https://doi.org/10.1029/2008GC002010

Grim, R.E., 1953. Clay Mineralogy: New York (McGrawHill).

Hagelberg, T., Shackleton, N., Pisias, N., and Shipboard Scientific Party, 1992. Development of composite depth sections for Sites 844 through 854. In Mayer, L., Pisias, N., Janecek, T., et al., Proceedings of the Ocean Drilling Program, Initial Reports, 138: College Station, TX (Ocean Drilling Program), 79-85. https://doi.org/10.2973/ odp.proc.ir.138.105.1992

Hagelberg, T.K., Pisias, N.G., Shackleton, N.J., Mix, A.C., and Harris, S., 1995. Refinement of a high-resolution, continuous sedimentary section for studying equatorial Pacific Ocean paleoceanography, Leg 138. In Pisias, N.G., Mayer, L.A., Janecek, T.R., Palmer-Julson, A., and van Andel, T.H. (Eds.), Proceedings of the Ocean Drilling Program, Scientific Results, 138: College Station, TX 
(Ocean Drilling Program), 31-46. https://doi.org/ 10.2973/odp.proc.sr.138.103.1995

Inwood, J., Brewer, T., Braaksma, H., and Pezard, P., 2008. Integration of core, logging and drilling data in modern reefal carbonates to improve core location and recovery estimates (IODP Expedition 310). Journal of the Geological Society, 165(2):585-596. https://doi.org/10.1144/ 0016-76492007-041

Inwood, J., Morgan, S., McGrath, A., Davies, S.J., Norry, M., and Foster, H., submitted. Data report: elemental data from Expedition 313 Sites M0027, M0028 and M0029 from X-ray fluorescence scanning of the split core surface and measurements on core samples. In Mountain, G., Proust, J.-N., McInroy, D., Cotterill, C., and the Expedition 313 Scientists, Proceedings of the Integrated Ocean Drilling Program, 313: Tokyo (Integrated Ocean Drilling Program Management International, Inc.).

Kinoshita, M., Tobin, H., Moe, K.T., and the Expedition 314 Scientists, 2008. NanTroSEIZE Stage 1A: NanTroSEIZE LWD transect. Integrated Ocean Drilling Program Preliminary Report, 314. https://doi.org/10.2204/ iodp.pr.314.2008

Lisiecki, L.E., and Herbert, T.D., 2007. Automated composite depth scale construction and estimates of sediment core extension. Paleoceanography, 22(4):PA4213. https:// doi.org/10.1029/2006PA001401

Meunier, A., 2006. Why are clay minerals small? Clay Minerals, 41(2):551-566. https://doi.org/10.1180/ 0009855064120205

Miller, K.G., Browning, J.V., Mountain, G.S., Bassetti, M.A., Monteverde, D., Katz, M.E., Inwood, J., Lofi, J., and Proust, J.-N., 2013. Sequence boundaries are impedance contrasts: core-seismic-log integration of OligoceneMiocene sequences, New Jersey shallow shelf. In Results of IODP Exp 313: The History and Impact of Sea-level Change Offshore New Jersey. Geosphere, 9(5):1257-1285. https://doi.org/10.1130/GES00858.1
Moran, K., 1997. Elastic property corrections applied to Leg 154 sediment, Ceara Rise. In Shackleton, N.J., Curry, W.B., Richter, C., and Bralower, T.J. (Eds.), Proceedings of the Ocean Drilling Program, Scientific Results, 154: College Station, TX (Ocean Drilling Program), 151-155. https:// doi.org/10.2973/odp.proc.sr.154.132.1997

Nilsson, A., Lee, Y.S., Snowball, I., and Hill, M., 2013. Magnetostratigraphic importance of secondary chemical remanent magnetizations carried by greigite $\left(\mathrm{Fe}_{3} \mathrm{~S}_{4}\right)$ in Miocene sediments, New Jersey shelf (IODP Expedition 313). Geosphere, 9(3):510-520. https://doi.org/ 10.1130/GES00854.1

Ruddiman, W.F., Cameron, D., and Clement, B.M., 1987. Sediment disturbance and correlation of offset holes drilled with the hydraulic piston corer: Leg 94. In Ruddiman, W.F., Kidd, R.B., Thomas, E., et al., Initial Reports of the Deep Sea Drilling Project, 94: Washington, DC (U.S. Govt. Printing Office), 615-634. https://doi.org/ 10.2973/dsdp.proc.94.111.1987

Saffer, D., Guo, J., Underwood, M.B., Likos, W., Skarbek, R.M., Song, I., and Gildow, M., 2011. Data report: consolidation, permeability, and fabric of sediments from the Nankai continental slope, IODP Sites C0001, C0008, and C0004. In Kinoshita, M., Tobin, H., Ashi, J., Kimura, G., Lallemant, S., Screaton, E.J., Curewitz, D., Masago, H., Moe, K.T., and the Expedition 314/315/316 Scientists, Proceedings of the Integrated Ocean Drilling Program, 314/315/316: Washington, DC (Integrated Ocean Drilling Program Management International, Inc.). https:// doi.org/10.2204/iodp.proc.314315316.218.2011

Sugawara, J., Yue, Z.Q., Tham, L.G., Law, K.T., and Lee, C.F., 2003. Weathered rock characterization using drilling parameters. Canadian Geotechnical Journal, 40(3):661-668. https://doi.org/10.1139/t03-007

Initial receipt: 24 January 2018

Acceptance: 21 June 2018

Publication: 25 September 2018

MS 313-202 
Figure F1. Overview of all identified overlaps across Holes M0027A, M0028A, and M0029A. For a more detailed scale, refer to OverlapsSummary_detail.ai in OVERLAP in "Supplementary material." Core depths are in meters below seafloor (CSF-A), and downhole logging depths are in meters wireline depth below seafloor (WSF; see IODP Depth Scales Terminology at http://www.iodp.org/top-resources/program-documents/policiesand-guidelines). Column numbers (red): $1=$ depth, $2=$ lithostratigraphic (sedimentological) units, $3=$ core boundaries (every tenth core run marked), $4=$ lithology, $5 \mathrm{a}=$ identified overlap intervals (black bars) from measured depths on the Multisensor Core Logger, $5 \mathrm{~b}=$ identified intervals overlap shaded, excluding the core catcher, $6=$ relevant notes taken during drilling operations accompanied by interpretations of how the core depths are most accurately corrected in the overlap intervals with sequence boundaries on the right, $7=$ downhole (red) and recovered core (black) natural gamma radiation (NGR) measurements, $8=$ annotations for types of overlap discussed in the text. See the "Methods" chapter (Expedition 313 Scientists, 2010a) for lithostratigraphic unit, lithology pattern, and sequence boundary definitions. This figure is available in an oversized format.
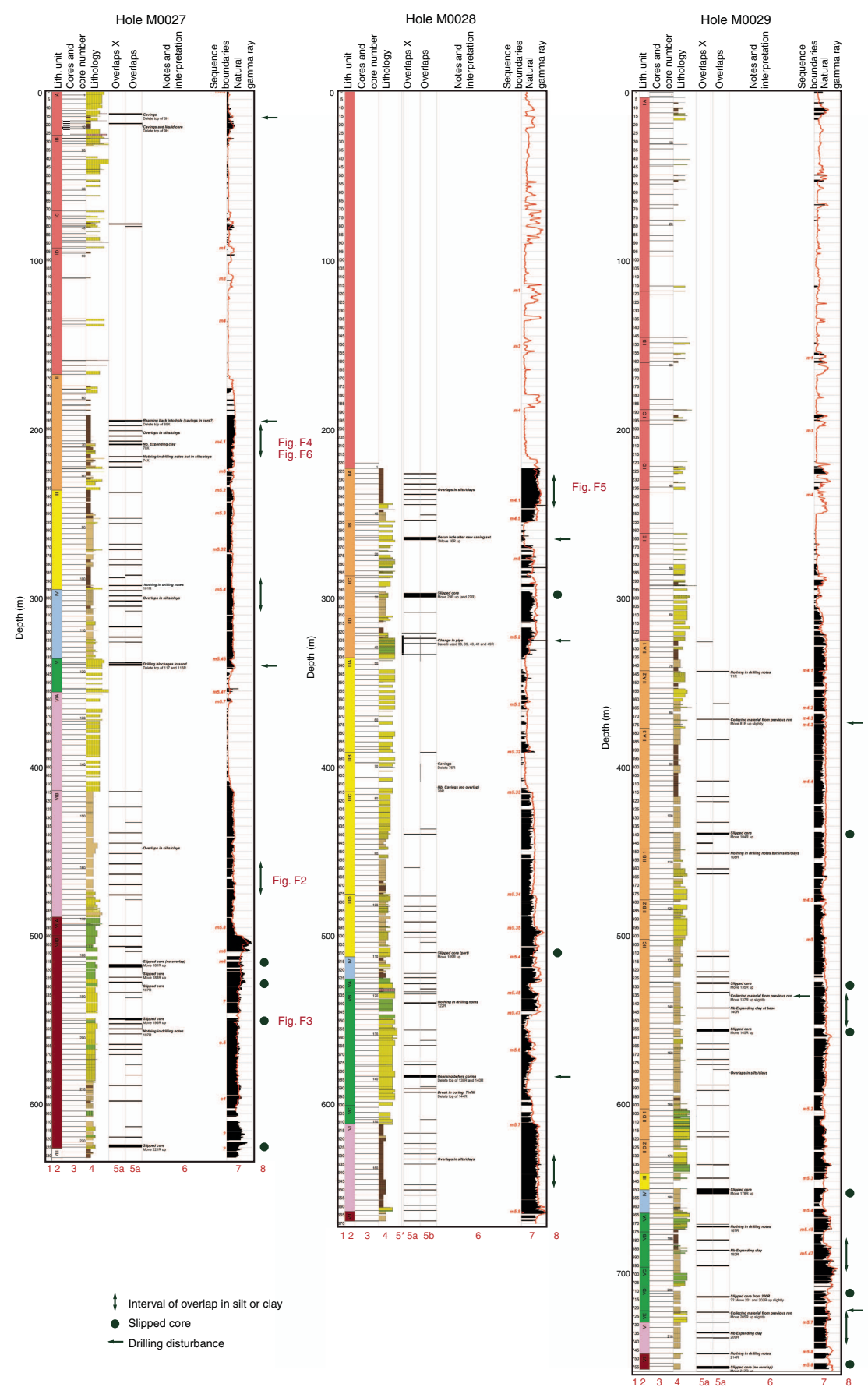

Interval of overlap in silt or clay

- Slipped core

$\leftarrow$ Drilling disturbance 
Figure F2. Coring runs in the expanding clay interval, Hole M0027A. See Figure F4 in the "Methods" chapter (Expedition 313 Scientists, 2010a) for lithology pattern definitions. Red arrows = correlation between depth (CSF-A) and time. Refer to Figure F1 for location within the borehole.

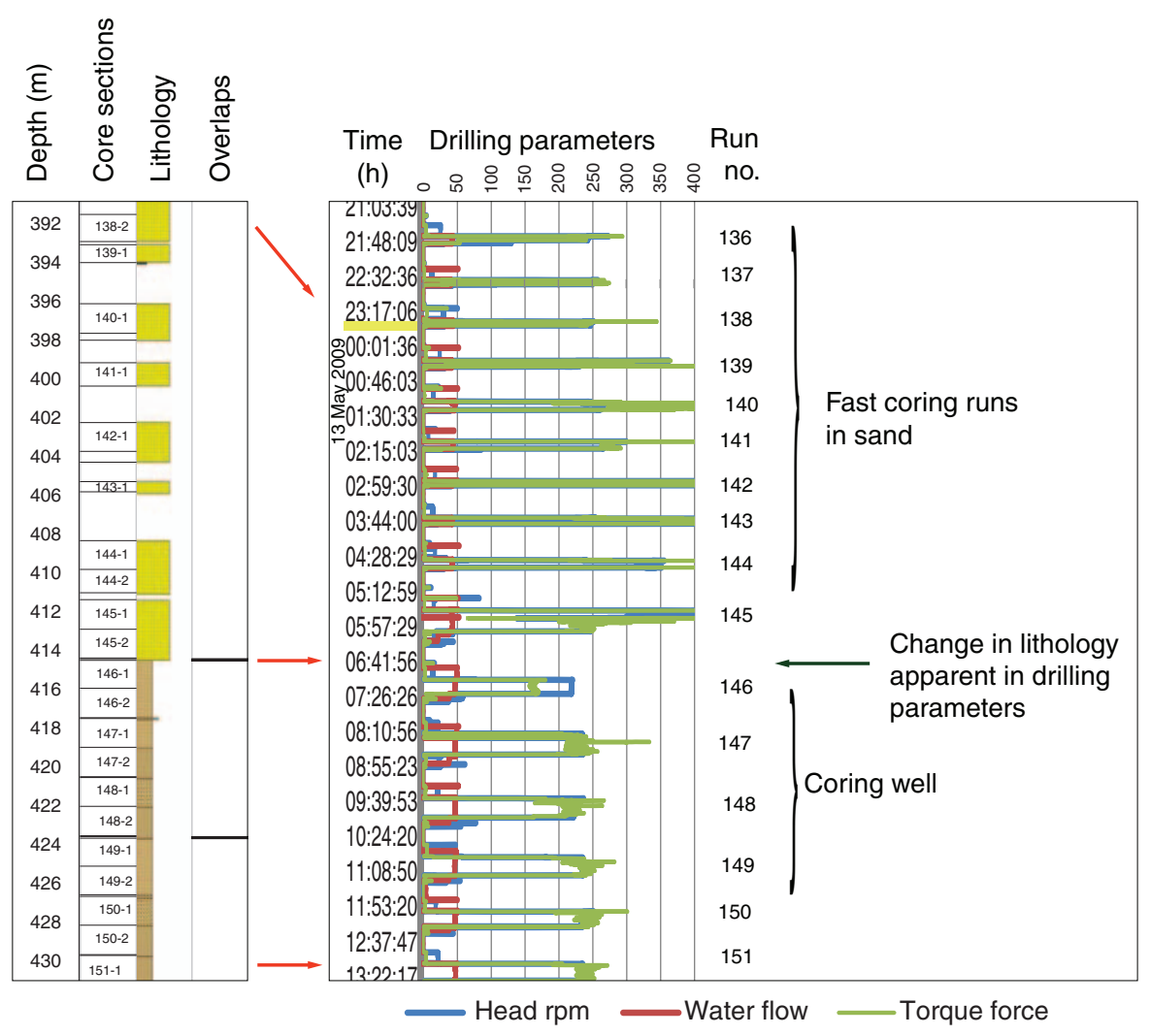


Figure F3. Coring runs with drilling disturbance, Hole M0027A. See Figure F4 in the "Methods" chapter (Expedition 313 Scientists, 2010a) for lithology pattern definitions. Red arrows = correlation between depth (CSF-A) and time. Refer to Figure F1 for location within the borehole.
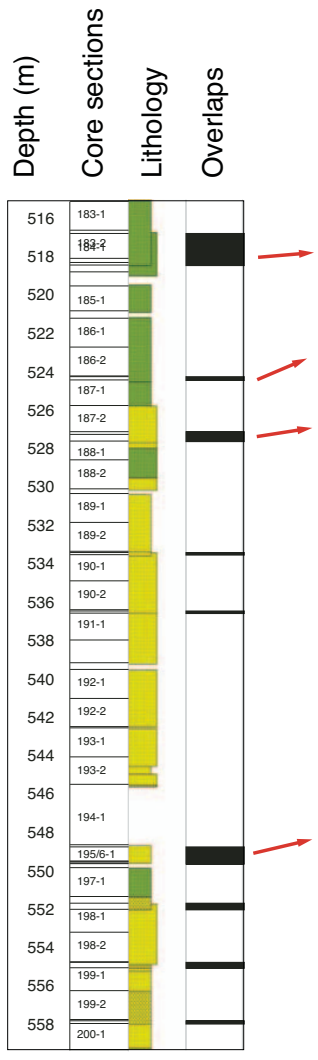

Time Drilling parameters Run

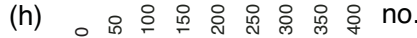

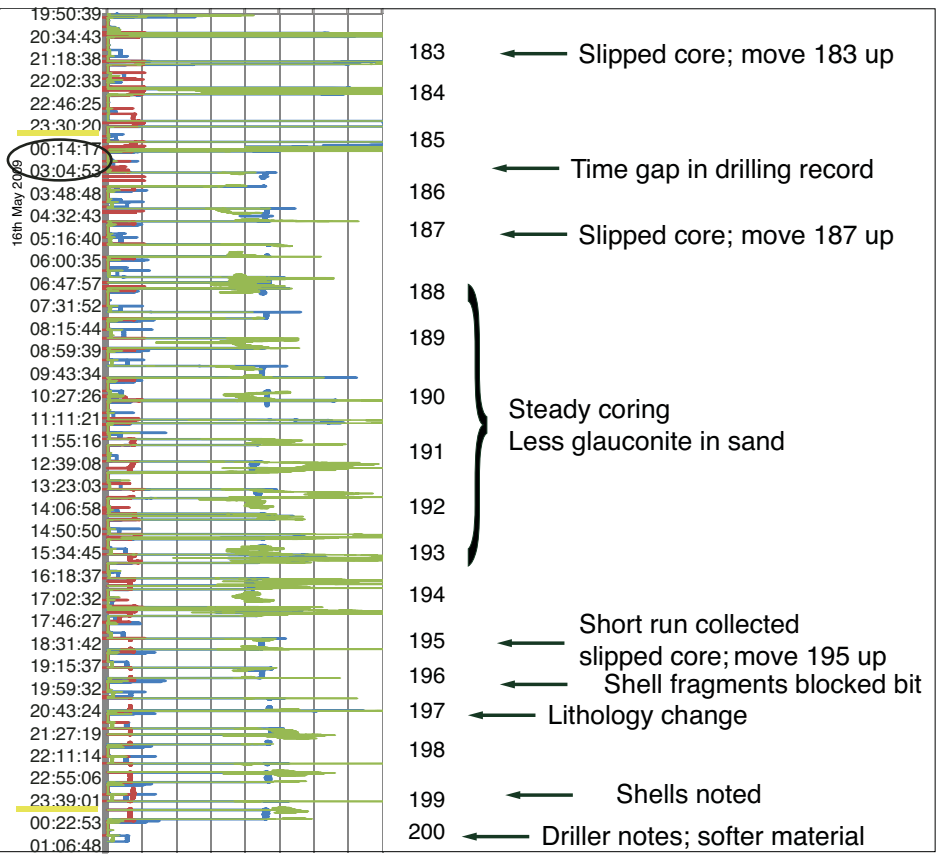

Head rpm Water flow Torque force 
Figure F4. Upper expanding clay interval, Hole M0027A. Column numbers (red): $1=$ depth (CSF-A with the exception of Column 6), 2 = core sections, 3 = lithology (see Figure F4 in the "Methods" chapter [Expedition 313 Scientists, 2010a] for lithology pattern definitions), 4 = overlaps (black bars), $5=$ digital lines scan images at conventional depth, $6=$ digital linescan images at expanded depth (note that the expanded depth used here is not a conventionally used IODP depth scale), 7-18 = digital linescan images at conventional depth but separated to show overlapping intervals. Refer to Figure F1 for location within the borehole.

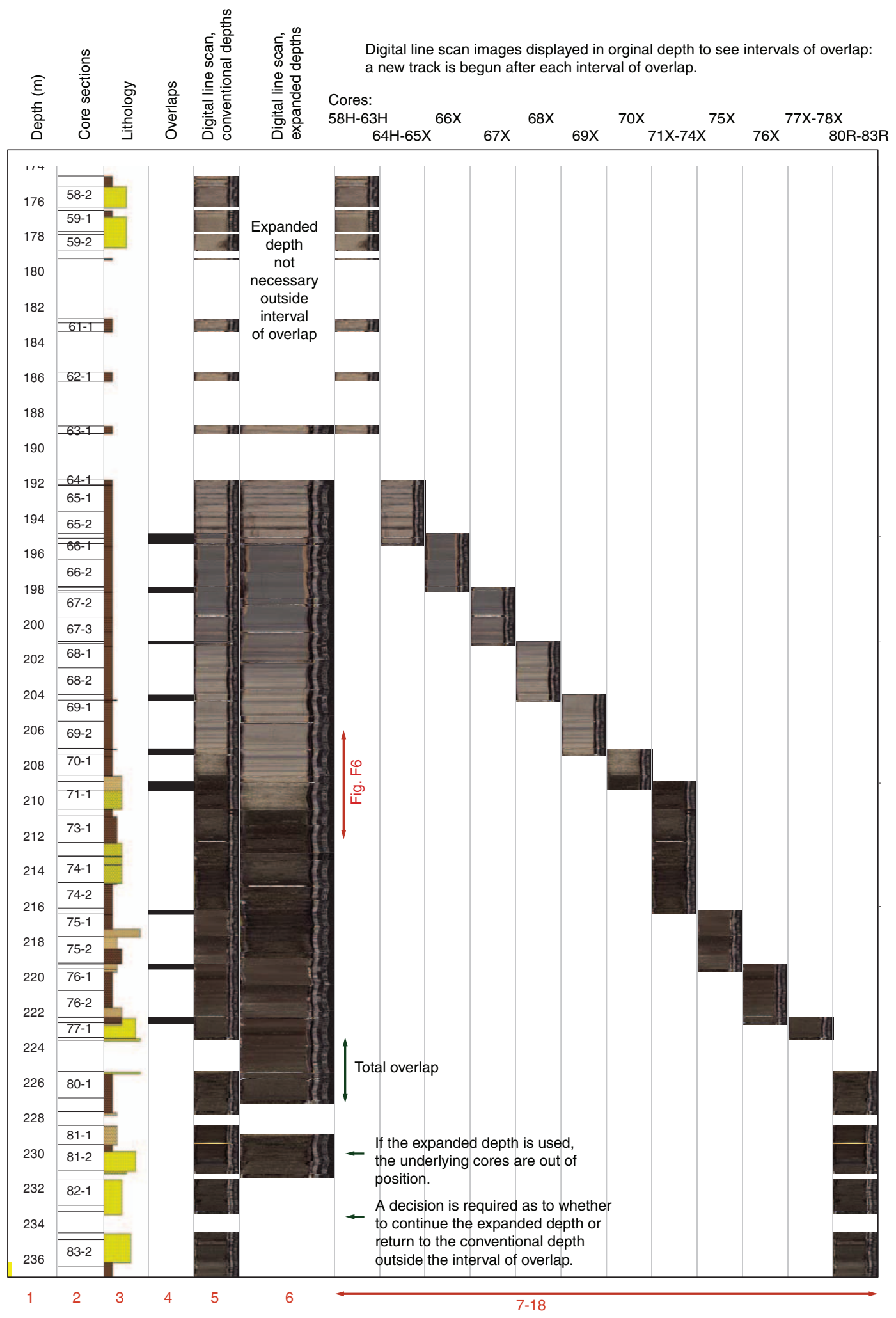


Figure F5. Upper expanding clay interval, Hole M0028A. Column numbers (red): $1=$ depth (CSF-A with the exception of Column 6), 2 = core sections, 3 = lithology (see Figure F4 in the "Methods" chapter [Expedition 313 Scientists, 2010a] for lithology pattern definitions), 4 = overlaps (black bars), $5=$ digital lines scan images at conventional depth, $6=$ digital linescan images at expanded depth (note that the expanded depth used here is not a conventionally used IODP depth scale), 7-18 = digital linescan images at conventional depth but separated to show overlapping intervals. Refer to Figure F1 for location within the borehole.

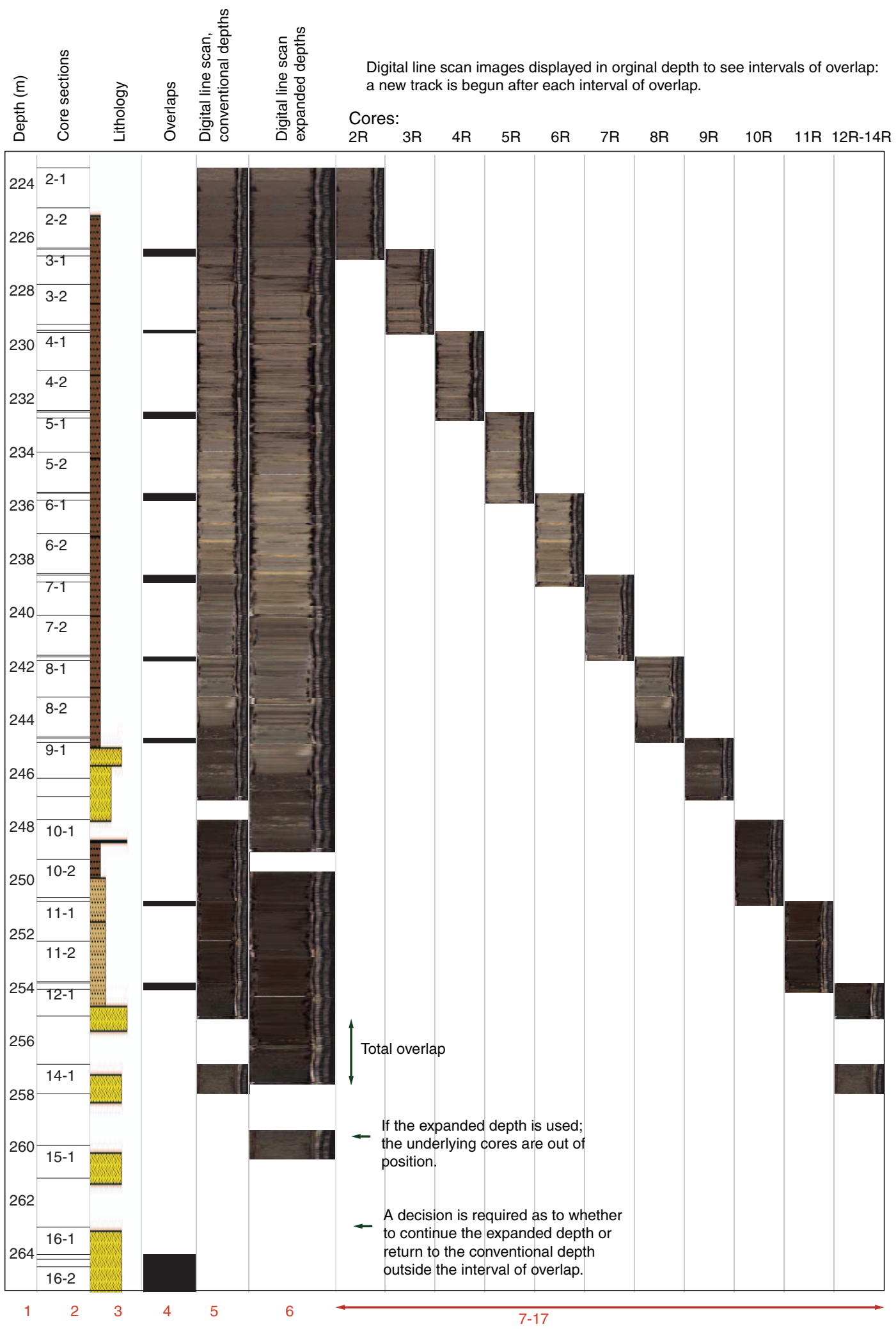


Figure F6. Expanding clay interval, Hole M0027A. Column numbers (red): $1=$ depth (CSF-A, except where specified; refer to IODP Depth Scales Terminology at http://www.iodp.org/top-resources/program-documents/policies-and-guidelines), 2 = lithology (see Figure F4 in the "Methods" chapter [Expedition 313 Scientists, 2010a] for lithology pattern definitions), 3 = digital linescan images separated to show overlaps, $4=$ overlaps (black bars), 5 = digital linescan images at conventional depth, $6=$ digital linescan images at scaled depth (CSF-B), 7 = digital linescan images at expanded depth (not a conventionally used IODP depth scale), 8 = key magnetic susceptibility downhole log changes. Core magnetic susceptibility at the same depth scale as the associated core data (dark blue) and wireline magnetic susceptibility (light blue; WSF) are overlain on Columns 5-7. Note that the core magnetic susceptibility is shown as a log scale for Columns 5 and 6 and as a linear scale for Column 7 (see text). A, B, C = key changes in core magnetic susceptibility. Refer to Figure F1 for location within the borehole and Figure $\mathrm{F} 4$ for location within the clay interval.

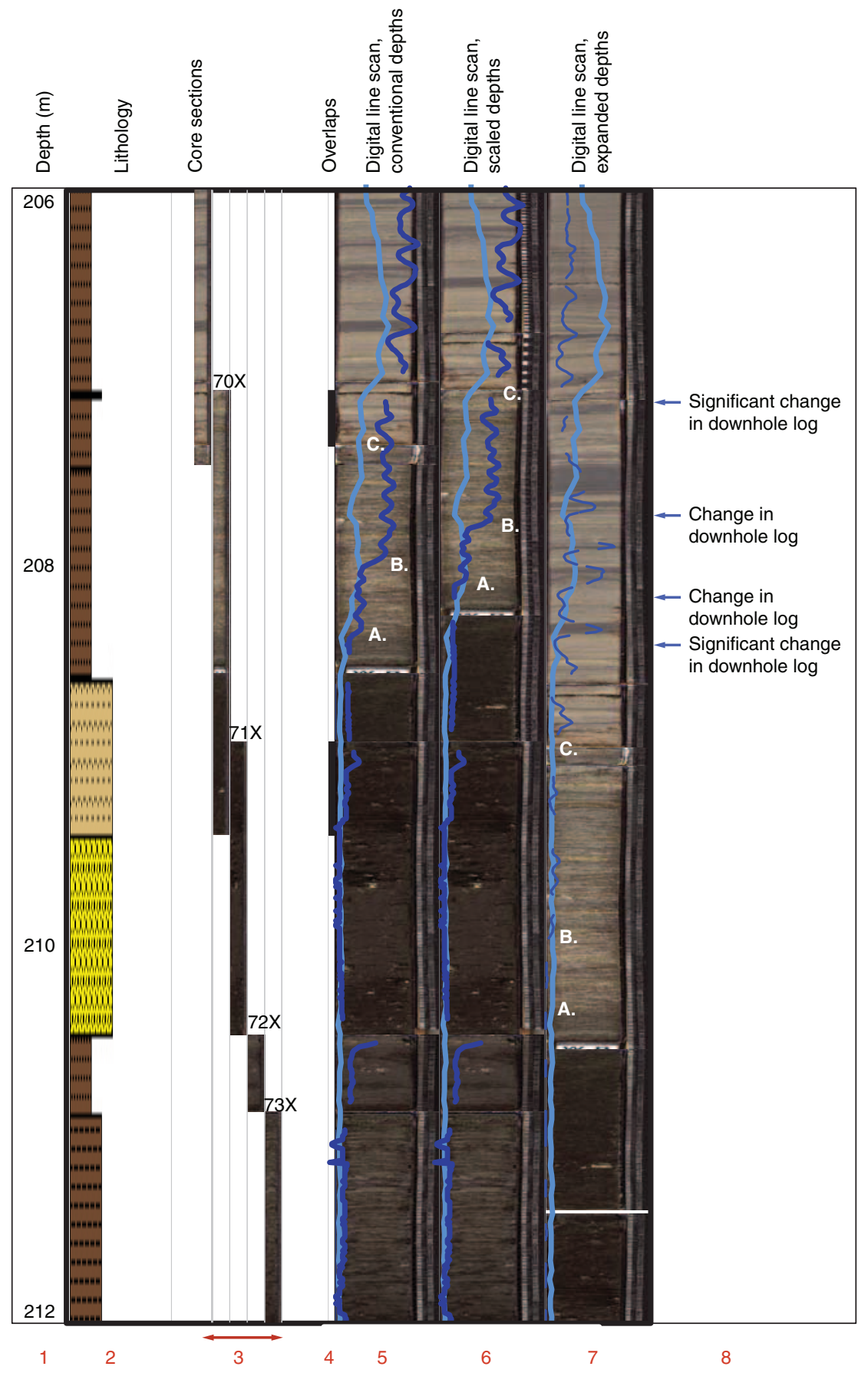

